\title{
HYPOCRITES OR PIOUS SCHOLARS? THE IMAGE OF THE PHARISEES IN SECOND TEMPLE PERIOD TEXTS AND RABBINIC LITERATURE
}

\author{
Etka Liebowitz*
}

\begin{abstract}
This article focuses upon Josephus' portrayal of the Pharisees during the reign of Queen Alexandra, relating it to their depiction in other contemporary sources (the New Testament, Qumran documents) as well as rabbinic literature. The numerous hostile descriptions of the Pharisees in both War and Antiquities are examined based upon a philological, textual and source-critical analysis. Explanations are then offered for the puzzling negative description of the Pharisees in rabbinic literature (bSotah 22b), who are considered the predecessors of the sages. The hypocrisy charge against the Pharisees in Matthew 23 is analyzed from a religious-political perspective and allegorical references to the Pharisees as "Seekers of Smooth Things" in Pesher Nahum are also connected to the hypocrisy motif. This investigation leads to the conclusion that an anti-Pharisee bias is not unique to the New Testament but is also found in Jewish sources from the Second Temple period. It most probably reflects the rivalry among the various competing religious/political groups and their struggle for dominance.
\end{abstract}

Who were the Pharisees - a small religious sect, an influential political party, or a mass movement? Attempts to define and describe the phenomenon of the Pharisees have aroused considerable scholarly debate for decades. ${ }^{1}$ This article will focus upon Josephus' portrayal of the Pharisees during the reign of Queen Alexandra in The Judaean War and Judaean Antiquities and attempt to understand how it can shed light upon their depiction in other Second Temple period texts - the New Testament (Matthew) and Qumran documents (Pesher Nahum), as well as in rabbinic literature (bSotah).

\footnotetext{
* The Schechter Institute of Jewish Studies, Jerusalem, Israel. Email: etka.liebowitz@mail.huji.ac.il. This article is based on a chapter from my Ph.D. dissertation, which has been significantly revised and expanded. I wish to thank Rivkah Fishman-Duker for reading this article and for her helpful comments and suggestions. I also express my appreciation to Shamma Friedman for his assistance with bibliographic references.

${ }^{1}$ A comprehensive examination of the Pharisees is beyond the scope of this article. Following is a sampling of studies on Josephus and the Pharisees: Albert Baumgarten, "The Name of the Pharisees," Journal of Biblical Literature 102 (1983): 411-428; Shaye Cohen, "Parallel Traditions in Josephus and Rabbinic Literature," Proceedings of the Ninth World Congress of Jewish Studies (Jerusalem: World Union of Jewish Studies, 1986), 7-14; David Goodblatt, "The Place of the Pharisees in First Century Judaism: The State of the Debate," Journal for the Study of Judaism 20:1 (1989): 1230; Martin Goodman, "A Note on Josephus, the Pharisees and Ancestral Tradition," Journal of Jewish Studies 50 (1999): 17-20; Martin Hengel and Roland Deines, "E.P. Sanders' 'Common Judaism,' Jesus, and the Pharisees," Journal of Theological Studies 46, no. 1 (April 1995); Gustav Hölscher, s.v. "Josephus," in Paulys Realencyclopädie der klassischen Alertumswissenschaft 9 (Stuttgart: J. B. Metzler 1916), cols. 1934-2000; Gustav Hölscher, Die Quellen des Josephus (Leipzig: Teubner, 1904); Jacob Neusner, From Politics to Piety (Providence: Prentice Hall, 1973); Jacob Neusner and Bruce Chilton, eds., In Quest of the Historical Pharisees (Waco, Texas: Baylor U. Press, 2007); Anthony Saldarini, "Pharisees," Anchor Bible Dictionary, vol. 3 (New York: Doubleday, 1992), 289-303; Morton Smith, "Palestinian Judaism in the First Century" in Israel, Its Role in Civilization, ed. Davis, Moshe (New York: Israel Institute of the Jewish Theological Seminary of America, 1956), 67-81. For an in-depth treatment of the Pharisees and Josephus, see Steve Mason, Flavius Josephus on the Pharisees: A Composition-Critical Study (Leiden: Brill, 1991, 2001).
} 
Josephus first mentions the Pharisees in War in connection with the ascent to the throne of Queen Alexandra, ${ }^{2}$ the first (and only) Jewish woman who reigned as an independent queen in Judaea:

But growing besides her as she achieved authority the Pharisees arose - a certain band

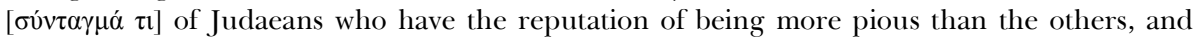
they accurately proclaim the (ancient ancestral) laws. ${ }^{3}$ (War $1: 110$ )

The vocabulary in this passage reveals a subtly disapproving attitude towards Pharisees. This is shown, for example, by the use of súntagma ( $\sigma u ́ v \tau \alpha \gamma \mu \alpha ́$ ) band, which Steve Mason

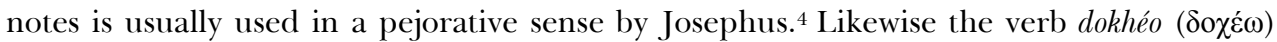
suggests an unfavorable approach towards the Pharisees. According to Mason, the definition of the Pharisees in War 1:110 hinges on this verb. ${ }^{5} \mathrm{He}$ interprets dokhéo as "having the reputation of being" for "it was the Pharisees reputation for piety that won them the support of Alexandra Salome." 6 Yet Mason posits that dokhéo means that the Pharisees only appeared to be pious while, on the other hand, Alexandra was genuinely pious. The Pharisees subsequent actions - "killing whomever they wished on false charges" - demonstrated that they were, actually, "wolves in sheep's clothing." 7 As we shall see, Josephus' extremely critical attitude towards the Pharisees continues throughout the narrative on Queen Alexandra in War.

Interestingly, many scholars have used War 1:110 to bolster their hypothesis of the Pharisees being a mass movement with popular support, ignoring (or unaware of) its negative overtones. For example, Martin Goodman asserts that the Pharisees' "endorsement of ancestral tradition gave them great popularity." ${ }^{8}$ Martin Hengel and Roland Deines claim this passage demonstrates that the Pharisees had great authority: “... the Pharisees' claim to be the carriers and continuers of this tradition worked in combination with their dépí $\beta \varepsilon 1 \alpha$ [accuracy] in scriptural interpretation and their strict manner of life to strengthen their authority in the eyes of the people." ${ }^{9}$

On the other hand, Jacob Neusner views the Pharisees as only one of many political parties during the Hasmonean era (a party of "philosophical politicians"), whose political life ended with Herod's rule. ${ }^{10}$ In contrast, Daniel Schwartz believes that Josephus' description of the Pharisees is actually a protective device inasmuch as "BJ reflects

\footnotetext{
2 The Pharisees are mentioned only briefly in Josephus' works - six other times in War (1:112, 1:571, 2:119, 2:162, 2:166, 2:411) as well as thirty-five times in Antiquities and Life. Steve Mason notes that "[a]ny interpretation of Josephus's Pharisees must reckon with a basic fact, all too often overlooked. Namely, the group figures only incidentally in his thirty volumes." See Steve Mason, "Josephus's Pharisees" in Neusner and Chilton, Historical Pharisees, 4.

3 This and all subsequent translations of War and Antiquities are my own, unless otherwise noted.

${ }^{4}$ Steve Mason, "War 1:107-114: The Pharisees and Alexandra Salome, I," in Flavius Josephus on the Pharisees, 84-

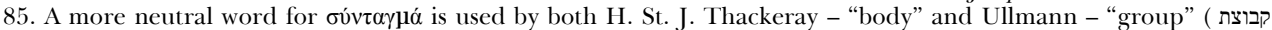
יהודים). See H. St. J. Thackeray, Josephus, The Jewish War (Cambridge, MA: Harvard University Press 1927), 53 and Lisa Ullmann, Yosef Ben Matityahu [Titus] Flavius Josephus, History of the Jewish War Against the Romans [Hebrew] (Jerusalem: Carmel 2009), 107.

${ }^{5}$ Mason, "Pharisees and Alexandra," 106.

${ }^{6}$ Ibid., 110.

7 Ibid., 111.

${ }^{8}$ Martin Goodman, "A Note on Josephus," 20.

${ }^{9}$ Hengel and Deines, "Common Judaism," 38.

${ }^{10}$ Neusner, Politics to Piety, 45-66.
} 
Josephus' attempt to portray the Pharisees, incorrectly, but safely, as uninvolved in politics and certainly as uninvolved in rebellion." 11

Nevertheless, Josephus' motives for writing this passage do not change the impression that it conveys to the reader - that, based on Mason's translation, the Pharisees are a devious group. If so, this would also indicate that they did not enjoy widespread support.

The Pharisees are again the focus of matters in War 1:113:

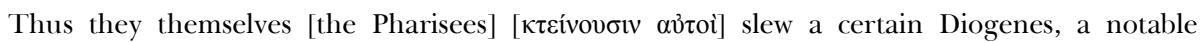
person, a friend of Alexander, having charged him with being an advisor concerning the 800 (men) who had been crucified by the king. They urged Alexandra to destroy the others too who had incited Alexander against them; and she yielded, being superstitious, and they killed whomever they wished.

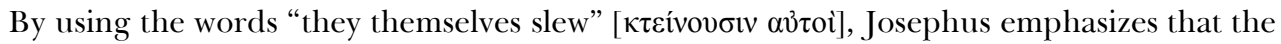
Pharisees are the ones responsible for killing Diogenes, and not Alexandra. Once again, Josephus severely criticizes the Pharisees, accusing them of being cruel and bloodthirsty.

Let us now examine the description of the Pharisees in Josephus' later work. ${ }^{12}$ Antiquities adds a whole new block of information - the account of Alexander Jannaeus' deathbed bequest of the kingdom to his wife, Alexandra, and his advice for keeping it secure, which has no parallel in War.

Then, she should go as from a brilliant victory to Jerusalem, support the Pharisees, [and] grant them some power, for they, by giving her approval in exchange for these honors, would render the people well disposed to her, and he said, these [Pharisees] have much power among the Judaeans - both hurting those that they hate while helping those with whom they are friendly. For they are highly trusted by the people, even when they speak harshly of someone due to envy, and he himself had come into conflict with the people due to these [Pharisees] ... (Ant. 13: 401-402)

Jonathan Goldstein believes that the death-bed scene appears only in Josephus' later work since "in later life Josephus became more and more sympathetic to the Pharisees" and that it "looks very much like Pharisaic propaganda." 13 Yet this theory does not accord with the tone of the narrative. For example, the phrase "these [Pharisees] have much power among the Judaeans - both hurting those that they hate while helping those with whom they are friendly" is not very complimentary to the Pharisees. ${ }^{14}$

\footnotetext{
${ }^{11}$ Daniel Schwartz, "Josephus and Nicolaus on the Pharisees," Journal for the Study of Judaism 14 (1983), 169.

${ }^{12}$ According to Christopher P. Jones, $79 \mathrm{AD}$ is the terminus ante for most of War and $81 \mathrm{AD}$ for its completion (Christopher Jones, "Towards a Chronology of Josephus," Scripta Classica Israelica 21 [2002], 114). The dating of Antiquities is clearer as Ant. 20:267 relates that it was completed in the "13th year of the reign of Domitian Caesar," that is, 93/94 CE. Ibid; see also Daniel Schwartz, trans., Flavius Josephus, Vita: Introduction, Hebrew Translation, and Commentary [Hebrew] (Jerusalem: Yad Ben Zvi, 2007), 4.

${ }^{13}$ Jonathan Goldstein, "The Hasmonean Revolt and the Hasmonean Dynasty," in The Cambridge History of Judaism, eds. W. Davies and L. Finkelstein, vol. 2 (Cambridge: Cambridge University Press 1989), 343.

${ }^{14}$ Indeed, Daniel Schwartz notes that this passage expresses the Pharisees' influence in a "nasty way," see Schwartz, "Josephus and Nicolaus," 159, and the entire article.
} 
Some scholars have claimed that source-critical theories can account for Josephus' hostile attitude towards the Pharisees in Antiquities. Viewing the term $\varphi \theta$ óvos [envy] ${ }^{15}$ in Jannaeus' deathbed oration as part of a recurring motif of "success followed by envy" in Josephus' writings, Israel Shatzman contends Josephus took the original version of the story in War and then inserted the accusation that the Pharisees were moved by envy in Antiquities. ${ }^{16}$ Shatzman concludes that inasmuch as Josephus was proud of his Hasmonean ancestry, this negative description of a Hasmonean monarch could only be due to Josephus' source, Nicolaus of Damascus, who often used the motif of "success followed by envy." 17 Likewise, Daniel Schwartz also attributes the passages in Antiquities hostile to the Pharisees to his source, Nicolaus. ${ }^{18}$ He posits that Josephus' earlier work, War, reflects an attempt to show that the Pharisees were uninvolved in politics and hence uninvolved in the Jewish rebellion against Rome. Josephus was less cautious about mentioning Pharisaic political involvement in Antiquities, according to Schwartz, since the Jewish rebellion against Rome was almost twenty years past. ${ }^{19}$ Other scholars also suggest that Josephus relied more upon Nicolaus in Antiquities than in War. ${ }^{20}$

Nevertheless, not all of Josephus' descriptions of the Pharisees in Antiquities are negative. Let us now turn to several complimentary passages concerning the Pharisees. In describing Alexandra taking the reins of government, Josephus states:

So after Alexandra had taken the citadel, she talked with the Pharisees as her husband had counseled, and offered them all matters connected to his corpse and the kingdom, and their wrath against Alexander ceased, and she made them well-disposed and friendly. (Ant. 13:405)

The phrase "she made them [the Pharisees] well-disposed and friendly" demonstrates a major difference in the interaction between Alexandra and the Pharisees in War and Antiquities. War only mentions her delegation of authority to the Pharisees (1:111) but Antiquities adds the dimension of friendly and cordial relations. Likewise, Ant. 13:408 emphasizes Alexandra's support of the Pharisees' authority:21

Thus, even any minor regulation which had been introduced by the Pharisees and revoked by her father-in-law Hyrcanus, even that she once again restored.

${ }^{15}$ Henry George Liddell, An Intermediate Greek-English Lexicon: Founded upon the Seventh Edition of Liddell and Scott's Greek-English Lexicon (Oxford: Clarendon Press, 1945), s.v. " $\varphi$ óvo૬,” 861, defines this as "ill-will, envy, jealousy."

${ }^{16}$ Israel Shatzman, "Success Followed by Envy: The Greek Tradition and Josephus" [Hebrew], in Essays in Memory of Menachem Stern and Studies Following his Works [Hebrew] (Jerusalem: The Israel Academy of Sciences, 2002), 36-54. Shatzman notes that envy connected to success, related to historical reports or events, appears dozens of times in Josephus' writings, e.g. Life 80, 122; Ant. 2:10, 2:13, 6:58-58, 2:199-202, 10:250, 13:288; War 1:208, 1:68, 1:72 (46$50)$.

${ }^{17}$ Ibid., 50-53.

${ }^{18}$ Schwartz, "Josephus and Nicolaus," 162.

19 Ibid., 169-170.

${ }^{20}$ See Menahem Stern, Greek and Latin Authors on Jews and Judaism, vol. 1 (Jerusalem: Israel Academy of Sciences and Humanities, 1976), 229; Cohen, "Josephus and His Sources," 48-66; Tal Ilan, "Josephus and Nicolaus on Women," in Geschichte-Tradition-Reflexion, eds. Hubert Cancik, Hermann Lichtenberger, and Peter Schäfer (Tübingen: Mohr Siebeck, 1996), 223-224, 240-241. On the other hand, Laqueur believes that the differences between War and Antiquities are due to Josephus' changing viewpoint, see Richard Laqueur, Der Jüdische Historiker Flavius Josephus: Ein Biographischer Versuch auf neuer quellenkritischer Grundlage (Giessen: Münchow'sche Verlagsbuchhandlung, 1920), 133-134, 261-263.

${ }^{21}$ This passage is related to Ant. 13:296-297, which describes how the Sadducees convinced John Hyrcanus to cancel Pharisaic laws. 
Why did the Pharisees have such good relations with Queen Alexandra? Pharisaic support of Queen Alexandra could be due to the fact that her reign separated religion and state. As a woman, Queen Alexandra could not serve as a high priest hence she delegated the priesthood to her eldest son Hyrcanus II while retaining secular powers, especially in foreign affairs. ${ }^{22}$ Thus cordial relations between the Pharisees and Alexandra were in the interests of both parties - Alexandra required the Pharisees' support in order to acquire legitimacy for her reign and the Pharisees supported Alexandra in order to gain control of religious affairs. ${ }^{23}$ This friendly relationship adds a very favorable element to the portrayal of the Pharisees.

These sympathetic passages in Antiquities have prompted many scholars to assume that Josephus supported the Pharisees and that they represented a popular movement. ${ }^{24}$ Moreover, it is presumed that Josephus even became a Pharisee himself, based upon the following accepted translation of one passage in Life $12^{25}$ :

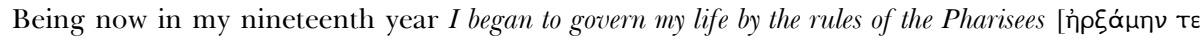

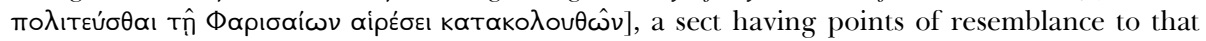
which the Greeks call the Stoic school. ${ }^{26}$

In a ground-breaking study Steve Mason disputes the commonly held view that Josephus "wanted to present himself as a devoted Pharisee." ${ }^{27}$ Instead, Mason contends that Josephus, like the Sadducee opponents of the Pharisees, was compelled to follow Pharisee dictates due to their overwhelming influence. ${ }^{28}$ Consequently, this passage does not mean that Josephus himself became a Pharisee rather that:

${ }^{22}$ Daniel Schwartz points out that the Pharisaic opposition to Hasmoneans in general, and to Alexander Jannaeus in particular, was due to the fact that they "held it was not legitimate to join priesthood and monarchy." See Daniel Schwartz, "On Pharisaic Opposition to the Hasmonean Monarchy," in Studies in the Jewish Background of Christianity (Tübingen: J.C.B. Mohr, 1992), 53. On the other hand, David Goodblatt posits that "possession of the high priesthood continued to be an important source of legitimation for the Hasmonean dynasty until its end." Since Queen Alexandra did not hold the office of high priest, and this contradicted the model of what Goodblatt terms the "priestly monarchy," she therefore required the Pharisees' support in order to give an aura of religious legitimacy to her reign. See David Goodblatt, The Monarchic Principle: Studies in Jewish Self-Government (Tubingen: Mohr 1994), 26.

${ }^{23}$ For a discussion of the initial rift between the Pharisees and the Hasmoneans, see Avraham Schalit, "Internal Policy and Political Institutions" [Hebrew], in The Hellenistic Age [Hebrew], ed. Avraham Schalit (Jerusalem 1983), 182-186.

${ }^{24}$ For instance, Morton Smith claims that Josephus emphasizes the Pharisees' popularity in order to convince the Roman government to support the Pharisaic endeavor in Yavneh: "That [Roman] government must have been faced with the problem: Which group of Jews shall we support? ... Which Jews ... can command enough popular following to keep things stable in Palestine? To this question Josephus is volunteering an answer: The Pharisees ... ." See Smith, "Palestinian Judaism," 75-76. See also Lee Levine "The Political Struggle between Pharisees and Sadducees in the Hasmonean Period" [Hebrew], in Jerusalem in the Second Temple Period: Abraham Schalit Memorial Volume [Hebrew], eds. A. Oppenheimer, U. Rappaport and M. Stern (Jerusalem: Zalman Shazar, 1971 ), 69.

${ }_{25}$ For example, Shaye Cohen states that Life "declares that Josephus had always been, since his youth, a loyal follower of the Pharisees." See Shaye Cohen, "Josephus and His Sources," in Josephus in Galilee and Rome: His Vita and Development as a Historian (Leiden: Brill, 1979), 238. See also Jacob Neusner, "Josephus' Pharisees," Ex Orbe Religionum: Studia Geo Widengren Oblata, vol. 1 (Leiden: Brill, 1972), 231.

${ }^{26}$ Flavius Josephus, The Life and Against Apion, trans. H. St. J. Thackeray (Cambridge, MA: Harvard University Press, 1926, 1956), 7.

${ }^{27}$ See Steve Mason, "Was Josephus a Pharisee? A Re-Examination of Life 10-12," Journal of Jewish Studies 40, no. 1 (1989): 31, and the entire article; see also Mason, Flavius Josephus on the Pharisees, 342-356.

${ }^{28}$ Mason, "Was Josephus a Pharisee," 42-43. 
Josephus's 'following of the Pharisaic school' was merely a necessary function of his entry into public life. It was not a deliberate choice of religious affiliation or a conversion ... Life 12 ... cannot justify the attribution of anti-Pharisaic passages in Josephus to some other source."29

Mason therefore offers a new (and in his opinion the correct) translation of the first six words of this passage:

Being now in my nineteenth year, I began to involve myself in polis affairs [or 'become politically involved'] ... following after [or 'following the authority of] the school of the Pharisees. ${ }^{30}$

Mason also contends that Antiquities regards "Alexandra's policy of cultivating the Pharisees as an unqualified disaster." ${ }^{31}$ He cites three passages in Antiquities in order to demonstrate that Josephus viewed the Pharisees as a calamity for both Queen Alexandra and the land of Judaea: 1) the Pharisees were "unprincipled power mongers" (13:406); 2) they slaughtered their enemies (13:412); and 3) the Hasmoneans lost the dynasty because of Alexandra's concessions to the Pharisees (13:430-432). ${ }^{32}$ Other passages in Antiquities also support Mason's claim of an anti-Pharisaic bias, e.g. "they [the Pharisees] were no different than despots" (13:409); "And the entire country was quiet except for the Pharisees, for they troubled the queen by entreating her to kill those who had advised Alexander to kill the eight hundred" (13:410); "Afterwards, they cut the throat of one of them, Diogenes, and following him, one after another" (13:411). Reports of such cruel acts by the Pharisees certainly would not encourage anyone to support them. ${ }^{33}$

The numerous hostile descriptions of the Pharisees in connection with Queen Alexandra's reign in both War and Antiquities could indicate that Josephus was not the only one to hold such a negative attitude towards this group. In fact, this might have been the outlook of a certain segment of Jewish society in the late Second Temple Period.

Rabbinic texts echo various episodes in Josephus accounts, including the phenomenon of the Pharisees during the reign of Queen Alexandra. ${ }^{34}$ Let us examine one such text:

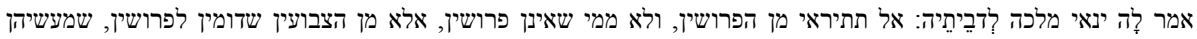

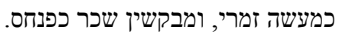

King Yannai said to his wife: "fear not the Pharisees nor those who are not Pharisees but the hypocrites who appear as if they are Pharisees because their deeds are like the deeds of Zimri but they request a reward like Phineas. ${ }^{35}$ (bSotah 22b)

\footnotetext{
${ }^{29}$ Mason, Flavius Josephus, 356.

${ }^{30}$ See Mason, "Josephus's Pharisees," 32.

${ }^{31}$ Mason, "Pharisaic Dominance," 369.

32 Ibid.

${ }^{33}$ In opposition to Mason, Shaye Cohen believes that "Alexander Jannaeus still has a few nasty things to say about the Pharisees, but, on the whole, these sectarians do better in AJ than in BJ." See Shaye Cohen, "Josephus and His Sources," 237.

${ }^{34}$ Rabbinic sources that mention Queen Alexandra include Sifra Lev BeHukotai 1:1, Sifrei Deut 42, bTa'anit 23a, bSotah 22a, bBerakhot 48a, Tosfot Shabbat 16 (from d'amar); Vayikra Rabba 35, Megillat Ta'anit 28th of Tevet. For an examination of parallel accounts in Josephus and rabbinic literature, see Shaye Cohen, "Parallel Traditions."

${ }^{35}$ Zimri was killed by Phineas the Priest for taking a Midianite wife and worshipping their gods (Num 25:1-16). Isidore Epstein, The Talmud: Sotah (London: Soncino, 1978), 22b, n. 7, believes that this refers to Josephus' account (Ant. 13: 17, 5) of a group of zealots requesting the assistance of Demetrius Eucarus, King of Syria, in their struggle against Alexander Jannaeus.
} 
This passage somewhat parallels King Alexander Jannaeus' (Yannai) advice to Queen Alexandra on his deathbed (Ant. 13:401), discussed above, which describes the Pharisees in hostile terms. Why does Yannai's warning appear here? The gemara is connected to the baraita in mSotah 3:4 (cited in bSotah 20a), interpreting the phrase "the plagues of Pharisees" [מכות פרושים]:

רבי יהושע אומר: רוצה אישה בקב ותפלות, מתשעה קבין ופרישות; והוא היה אומר, חסיד שוטה, רשע ערום, אישה פרושה, מכות פרושים--הרי אלו מבלי עומר: רוצח אישה בית

Rabbi Yehoshua says: A woman prefers one $\mathrm{kab}^{36}$ and sexual indulgence to nine $\mathrm{kab}^{37}$ and abstinence. He used to say: "a foolish pietist, a cunning evildoer, a female Pharisee, and the plagues of Pharisees - all of these bring destruction upon the world. ${ }^{38}$

There are two possible connections between $b$ Sotah $22 \mathrm{~b}$ and the above mishnah. According to Albeck's commentary on the Mishnah, "a female Pharisee" [אישה פרושה] has a positive context and refers to a woman who is zealous in her asceticism and modesty. This expression may therefore refer to Queen Alexandra, since she supported the Pharisees. On the other hand, Albeck notes that the phrase "the plagues of Pharisees" [מכות פרושים] denotes the evil Pharisees who are hypocritical and only outwardly act with asceticism: [המקולקלים שבפרושים, הצבועים שנוהגים בפרישות למראית עין The gemara may consequently be linking the Pharisees with Queen Alexandra, or with hypocritical actions, or both. Tal Ilan maintains that the word perishut [פרישות] in mSotah 3:4 should not be translated as abstinence but rather "the teachings of Pharisaism," which attracted women and which Rabbi Yehoshua viewed as dangerous. ${ }^{40}$ This also would connect Queen Alexandra, as a woman, with the Pharisees.

The description of the Pharisees in mSotah 3:4 has puzzled scholars since, on the one hand, it gives a very negative interpretation of anything connected to the word "Pharisee" [פרוש] while, on the other hand, they are considered the predecessors of the sages, and as such, are usually only regarded positively in rabbinic literature. Menahem Mansoor claims that this passage demonstrates that "the leaders were well aware of the presence of the insincere among their numbers." ${ }^{11}$ In other words, the Pharisees wanted to show that a small minority within their group were insincere.

Another explanation for the inclusion of this attack upon the Pharisees is connected to the origin of the name Pharisee. Solomon Zeitlin asserts that the Sadducees coined Pharisee as a term of contempt for those who advocated new laws and reforms. ${ }^{42}$ Ellis Rivkin supports Zeitlin's characterization and notes that the name "Pharisee" [פרוש] was given to this group by their opponents (the Sadducees), who "regarded these scholars as 'usurpers,' 'separatists,' 'heretics' ... ." 43 Tannaitic literature only uses the term Pharisee in

${ }^{36}$ A small amount, that is, a scanty livelihood.

${ }^{37}$ A large amount, that is, a luxurious living.

${ }^{38}$ For an in-depth examination of mSotah 3:4, see Tal Ilan, Silencing the Queen: The Literary Histories of Shelamzion and other Jewish Women (Leiden: Brill, 2006), 74-97.

${ }^{39}$ See Hanoch Albeck, The Six Orders of the Mishna [Hebrew] (Jerusalem: Mosad Bialik/Tel Aviv: Dvir, 1988), 241.

${ }^{40}$ Ilan, Silencing the Queen, 95-96. Although Ellis Rivkin emphatically states that perishut "means 'abstinence', 'continence', and not 'Pharisaism!" See Ellis Rivkin, "Defining the Pharisees: The Tannaitic Sources," HUCA 40-41 (1970): 243 .

${ }^{41}$ See Encyclopedia Judaica, s.v. "Pharisees," 31.

42 Solomon Zeitlin, Studies in the Early History of Judaism, vol. 2 (New York: Ktav, 1974), 294-295.

${ }^{43}$ Ellis Rivkin, "Scribes, Pharisees, Lawyers, Hypocrites: A Study in Synonymity," HUCA 49 (1978), 140. Rivkin emphasizes that the Pharisees never called themselves Pharisees by citing mYadayim 4:6: "The Sadducees say, "We 
disputes with the Sadducees and otherwise it avoids using this name (instead they are termed sages or scribes, a scholar class). ${ }^{44}$ Thus, inasmuch as the rabbis usually did not identify themselves with the name "Pharisee" but rather viewed themselves as sages, tannaitic sources, such as mSotah 3:4, had no problem with an unfavorable description of a group called Pharisees.

Interestingly, the term Pharisees acquires a positive connotation in the gemara: there is no need to fear either those who are Pharisees [פרושין] or their opponents (probably the Sadducees), however those who we have to fear are the hypocrites [צבועין]. These hypocrites appear to act like Pharisees (which in this context means laudable acts) but actually behave like Zimri and rebel against God (commit evil acts). Thus the Pharisees themselves are not evil but rather those who masquerade as them and act sinfully. This analogy may indicate that the Babylonian rabbis were confronted with such a phenomenon in their time (and which has appeared throughout time!) - people who outwardly appeared religious but were not truly so in reality.

Richard Kalmin notes that prior to the pericope about Yannai and his wife, the gemara presents a statement by Rav Nahman bar Yizhak criticizing those who cloak themselves: ${ }^{45}$

אמר רב נחמן בר יצחק דמטמרא מטמרא ודמגליא מגליא בי דינא רבה ליתפרע מהני דחפו גונדי

That which is hidden is hidden. That which is revealed is revealed. The great [that is, heavenly] court will punish those who wrap themselves in cloaks. (bSotah 22b)

Kalmin believes that this also refers to the Pharisees due to the context, and that it therefore connects the Pharisees with hypocrisy (although this is mitigated by the subsequent story of Yannai).

Let us return to the rabbinic account of Yannai's advice to his wife. Scholarship is divided as to whether rabbinic texts that parallel Josephan accounts, such as bSotah 22b, are based upon Josephus' writings, or upon other earlier sources or if the Josephan narrative is "earlier than the rabbinic" and "Josephan parallels ... illuminate the ways in which the rabbis molded the traditions they received." 46 Some scholars believe that the tradents of the BT either read some version of Josephus or incorporated Josephus-like traditions into the BT. ${ }^{47}$ Due to the fact that the literary form of rabbinic texts date, at the earliest, to the third century, Shaye Cohen contends that "Josephan traditions are older and more "original' than the rabbinic" and that in some cases, the rabbinic accounts are derived from Josephus. ${ }^{48}$ In contrast, Shamma Friedman hypothesizes that "the fact that there are parallels in the Tosefta, Mishnah and Genesis Rabbah to most of the events

complain against you Pharisees because you say that Holy Scriptures renders the hands unclean” (ibid., 141). Here we see that it is the Sadducees who are calling the Pharisees as such.

${ }^{44}$ Rivkin, "Defining the Pharisees," 246-248.

${ }^{45}$ See Richard Lee Kalmin Mitigating Tales: The Talmud's Narratives and their Historical Context (Oakland, CA: University of California, 2014), 165-166.

${ }^{46}$ See Cohen, "Parallel Traditions," 14. Recently, Vered Noam has proposed that a rabbinic text that parallels Josephus, bKid 66a, is actually a Pharisaic polemical work, see Vered Noam, "The Story of King Jannaeus (b. Qiddušin 66a): A Pharisaic Reply to Sectarian Polemic," Harvard Theological Review 107:1 (January 2014): 3158. Noam also notes that she is now engaged on a research project on such parallel traditions.

${ }_{47}$ Shaye Cohen, "Parallel Traditions," 13. Based upon a striking parallel between another rabbinic and Josephan text (bKid 66a and Ant. 13:288), Richard Kalmin asserts that "It is not out of the question that Josephus himself was the rabbis' source." See Richard Lee Kalmin, Jewish Babylonia between Persia and Roman Palestine (New York: Oxford University Press, 2006), 56, see also 149-172.

${ }^{48}$ See Shaye Cohen, "Parallel Traditions," 8, and the entire article. 
described in Josephus' writings increases the probability that the descriptions that are solely in the Bavli did not reach it directly via Josephus' writings but rather through lost sources of Palestinian Talmudic literature." 49

As regards our text in particular, Tal Ilan asserts that bSotah 22b encompasses an oral tradition that preserves a better and earlier version of Alexander Jannaeus' deathbed statement than Josephus' description in Antiquities. ${ }^{50}$ Richard Kalmin maintains that, in the case of bSotah 22b and Ant. 13:398-404, "the story about Yannai and his wife reached Babylonia from the Roman East, and was reworked and placed in its present context ... some time between the fourth century and the final redaction of the Bavli." ${ }_{51}$ Whatever its source, bSotah 22b clearly encompasses a tradition similar to the account in Antiquities. Moreover, in the discussion of the baraita, the Bavli "acknowledges that there are several kinds of Perushim with negative attributes." 52 Furthermore, the very statement that the Perushim are not to be feared means that others $d o$ fear them, thereby revealing a rather unenthusiastic rabbinic attitude towards the Pharisees. ${ }^{53}$ If, as many scholars believe, $b$ Sotah 22b is based upon an earlier tradition (no matter what its source), then this story could also reflect the outlook of certain circles in the Second Temple period.

Not only does rabbinic literature provide a literary parallel with Josephus' writings, but its portrayal of the Pharisees as hypocrites also bears a striking similarity to the NT. Various passages in Matthew 23 either describe a hypocritical act by the Pharisees or designate the group itself as hypocrites. For example:

The scribes and the Pharisees sit on Moses' seat; so practice and observe whatever they tell you, but not what they do; for they preach but do not practice (Mt. 23:2-3) ${ }^{54}$

The term hypocrites and the idea of hypocrisy are repeated throughout the rest of chapter 23 in the seven woe oracles (Mt. 23:13, 15, 16, 23, 25, 27, 29), which contain the formula:

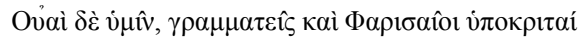

["Woe, woe to you scribes and Pharisees, hypocrites."]. ${ }^{55}$

What is the intention of Mt. 23:2-3? Is it indeed an attack upon the Pharisees? An examination of the wording reveals that this polemic acknowledges the authority of the Pharisees although it attacks their practices. For, as Goodman succinctly notes, "Jesus' objection here is quite explicitly not to the teachings of the Pharisees but to their alleged

\footnotetext{
${ }^{49}$ Friedman's assertion is based upon an analysis of bKid 66a and Ant. 13:288 and other sources. I thank Shamma Friedman for providing me with a copy of his unpublished lecture in Hebrew delivered at Tel Aviv University in 1990.

${ }^{50}$ Tal Ilan, Integrating Women into Second Temple History (Peabody, Mass: Hendrickson, 1999), 21-23.

${ }^{51}$ Kalmin Mitigating Tales, 169.

52 Ibid.

${ }^{53}$ Although, as Kalmin notes, rabbinic literature is not monolithic and includes both positive and negative portrayals of the Pharisees (ibid., 174).

${ }_{54} \mathrm{NT}$ quotations in English are from the RSV.

55 This formula is also used in Matt 23:15, 23, 25, 27, 29; 5:20, 12:38. NT quotations from Greek are from the Perseus website (http://www.perseus.tufts.edu) based on The New Testament in the Original Greek, text revised by Brooke Foss Westcott and Fenton John Anthony Hort (New York. Harper \& Brothers, Franklin Square. 1885). On the seven woe oracles, see Anthony Saldarini, Matthew's Christian-Jewish Community (Chicago and London: University of Chicago Press, 1994), 46-52.
} 
hypocritical failure to conform to their own advice." 56 Jacob Neusner believes that "the competition between the Pharisees and the Christian missionaries for the loyalty of the mass of Jews lies at the foundation of these sayings." ${ }_{57}$ According to Anthony Saldarini, this polemic indicates that the Pharisees represented the dominant leadership movement while the believers in Jesus constituted a minority reform movement. ${ }^{58}$ Therefore:

the author of Matthew seeks specifically to delegitimate rival Jewish leaders and legitimate himself and his group as the true leaders of Israel, accurate interpreters of the Bible and authentic messengers of God's will ... Thus Matthew writes as a member of the late first century Jewish community ... who is seeking influence and power in order to establish Jesus' way of life. ${ }^{59}$

David Garland also agrees that "this structural unit [the woe oracles] is entirely attributable to Matthew's editorial hand." ${ }^{60}$ Garland further asserts that “... it is possible that the charge goes back before Matthew to a Palestinian community or even to Jesus where a Hebraic coloring might be determinative."61 This supports the hypothesis that Matthew is describing a tendency that existed during Josephus' time ${ }^{62}$ - the Pharisees were not all as pious as they claimed to be. Indeed, this is exactly what Josephus states in Antiquities when he describes the Pharisees as pretenders who opposed the king:

There was also a segment of Jews that prided itself greatly on its extreme precise observance of

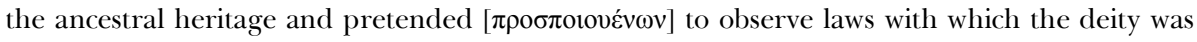
pleased. By them the female faction [or clique] was directed. Called Pharisees, these men were eminently capable of predictions for the king's benefit and yet, evidently, they rose up to combat and injure him. ${ }^{63}$ (Ant. 17:41)

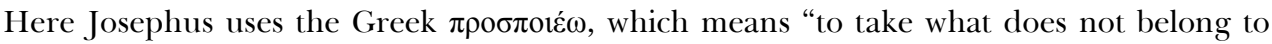
one, pretend to, lay claim to." 64 This word is quite similar in meaning to úpokrités metaphor for "a pretender, dissembler, hypocrite." 65

Thus we see that Josephus, the NT and rabbinic literature all associate the motif of hypocrisy, the contradiction between outward behavior and pronouncements, with the Pharisees. At the very least, this indicates a common tradition.

The origin of this hypocrisy motif has aroused much discussion. Based upon bSotah 22b, Anthony Saldarini suggests that the pejorative references to the Pharisees in the gemara are responding to Christian polemics in the fifth and sixth centuries: "the Talmudic authors defuse Christian criticism by agreeing with their attack on hypocritical Pharisees

${ }^{56}$ Goodman, “A Note on Josephus,” 19.

${ }^{57}$ Neusner, Politics to Piety, 77.

58 Anthony Saldarini, "Delegitimization of Leaders in Matthew 23," Catholic Bible Quarterly 54 (1992), 665.

${ }^{59}$ Ibid., 661.

${ }^{60}$ David Garland, The Intention of Matthew 23 (Leiden: Brill, 1979), 91.

${ }^{61}$ Ibid., 97.

${ }^{62}$ Martin Pickup points out that Matthew is "dated in the 80 s or 90 s at a time when the Pharisees appear to have risen in prominence and power." See Jacob Neusner and Bruce Chilton, eds., In Quest of the Historical Pharisees (Waco, Texas: Baylor U. Press, 2007), 67.

63 Translated by Steve Mason in "Pharisaic Dominance before $70 \mathrm{CE}$ and the Gospels' Hypocrisy Charge (Matt 23:2-3)," Harvard Theological Review 83 (1990), ${ }^{3} 69$.

${ }^{64}$ Liddell, Greek-English Lexicon, s.v. "זроблов́

${ }^{65}$ Ibid., s.v. "úrtokpıтń," def. 2, 844. 
and by separating some Pharisees and themselves from those being attacked." 66 Richard Kalmin contends that "the New Testament and the Bavli independently received the 'hypocrisy' and 'holier than thou' motifs from an earlier source ... either directly from the Roman East or indirectly via Syriac translations from Mesopotamia." 67 Steve Mason maintains that "the mere fact of Pharisaic dominance before $70 \mathrm{CE}$ may be the key to understanding Jesus' hypocrisy charge." Noting that "it is an observable phenomenon that leaders and policy-makers invariably attract the charge of hypocrisy from disaffected groups,"68 Mason concludes that:

Jesus ... joined others in denouncing the apparent hypocrisy of the policy-makers, without thereby questioning the legitimacy of their role as scriptural exegetes. But this authentic hypocrisy charge was naturally misconstrued by groups within the church ... and was reborn as an outright rejection of Pharisaic teaching. ${ }^{69}$

If Mason is correct, then the passage in Sotah may preserve the original meaning of the pericope in the New Testament as well as the Josephan passages - the Pharisaic teachings are not hypocritical per se and therefore should not be rejected, but rather the conduct of individual Pharisees is hypocritical.

Qumran texts also refer to the Pharisees, albeit allegorically. ${ }^{70}$ For example, Pesher Nahum 3:1 condemns the Pharisees in very harsh tones. It describes the "Seekers of Smooth Things" [דורשי החלקות], assumed to be a codename for the Pharisees, as conducting themselves in lies and falsehoods - בכחש ושקר]ים י[תהלכו.71 Garland points out that the term "Seekers of Smooth Things" "seems to possess somewhat the same ambiguity in meaning as ... the Greek word 'hypocrite." 72 In fact, he believes that there is a connection between the hypocrites in Mt. 23 and the "Seekers of Smooth Things" in Qumran literature since "[b]oth terms may connote dissimulation or deceit and false interpretation ... In both cases, the opposition to the Pharisees was not precipitated by moral outrage over their false character but by serious disputes involving the interpretation of Scripture." ${ }^{73}$ In opposition to Mason's theory that the NT hypocrites only refer to the Pharisees' political role, Garland believes that in the NT 'hypocrite' "may be rooted in Jesus' criticism of the Pharisees' false interpretation of the law, and it summarized their failure as God's appointed leaders .... ." 74

\footnotetext{
${ }^{66}$ Saldarini, "Pharisees," 300-301.

${ }^{67}$ Kalmin, Mitigating Tales, 167.

${ }^{68}$ Mason, "Pharisaic Dominance," 380.

69 Ibid., 381.

${ }^{70}$ A discussion of Qumran texts and the Pharisees is beyond the scope of this article. For further discussion, see David Flusser, Judaism of the Second Temple Period, trans. Azzan Yadin, vol. 1 (Jerusalem: Magnes, 2007), 218-220; Lawrence Schiffman, "Pharisees and Sadducees in Pesher Nahum," in Minha Le-Nahum: Biblical and Other Studies Presented to Nahum M. Sarna in Honor of His 70 Birthday, eds. Marc Brettler and Michael Fishbane (Sheffield: JSOT, 1993), 272-290; Saldarini, "Pharisees," 301-303; Anthony Saldarini, Pharisees, Scribes and Sadducees in Palestinian Society (Wilmington, Delaware: Michael Glazier Inc., 1988), esp. 279-280; James VanderKam, "Pesher Nahum and Josephus," in When Judaism and Christianity Began: Essays in Memory of Anthony J. Saldarini, eds. Alan J. Avery-Peck, Daniel Harrington and Jacob Neusner, vol. 1 (Leiden: Brill, 2004), 299-311.

${ }^{71}$ See Ilan, Silencing the Queen, 65, and Hanan Eshel, The Dead Sea Scrolls and the Hasmonean State [Hebrew] (Jerusalem: Yad Ben Zvi, 2004), 122.

72 Garland, Intention of Matthew, 107.

73 Ibid., 111.

${ }^{74}$ Ibid., 117.
} 
What can we conclude from the above analysis? First of all, we can perceive a common thread that runs through the various Second Temple Period sources - a critical and even hostile view of the Pharisees. War and Antiquities describe the Pharisees as devious and power-hungry; they do not shirk from any brutal means in order to obtain dominance. Matthew and Pesher Nahum label the Pharisees "hypocrites" or "pretenders," disputing their interpretation of Scripture and their status as religious leaders. This antagonistic attitude is due to the fact that these three sources represented religious/political groups opposed to the Pharisees: Josephus - the priestly elite, Mathew - the followers of Jesus, and Pesher Nahum - the Qumran community.

On the other hand, the rabbinic account in the Bavli dispelled the hypocrisy charge by distinguishing between the "real Pharisees" and those who act as if they are Pharisees but in reality are not. By separating the Pharisees (and perhaps themselves?) from pseudoPharisees (pretenders), the tradents of the rabbinic texts succeeded in turning around the Josephan and NT negative description of the Pharisees as hypocrites and thereby eliminated criticism of the group. ${ }^{75}$ Consequently, instead of Pharisees who "pretended to observe laws" (Ant 17: 41) and "preach but do not practice" (Mt. 23:3), they are only "not to be feared" (bSotah 22b) for the hypocrites [צבועין] represent the real danger. Nevertheless, the very fact that rabbinic literature felt a need to defend the Pharisees demonstrates that they were indeed subject to attack by other Jewish groups. And, by stating that "fear" was associated with the Pharisees, rabbinic literature demonstrates that they were not universally liked.

Thus, viewed against the background of other Second Temple Period sources and reactions to them, the NT's condemnation of the Pharisees does not appear to be so out of place. Indeed, it is possible that the NT was influenced by contemporary anti-Pharisee views, which stemmed from a struggle between the Pharisees and other groups for dominance.

Does that mean that this was indeed the true nature of Pharisaism? Not necessarily, for the Pharisees figure only marginally in Josephus' writings and, as an aristocratic priest, Josephus may be voicing the reservations of his class regarding the Pharisees. ${ }^{76}$ Likewise the NT would not approve of the Pharisees since they challenged Jesus' teachings. ${ }^{77}$ The Qumran community also viewed the Pharisees as a rival group - as liars, misleading others through speech. ${ }^{78}$ Consequently, we can only conclude that the Pharisees were viewed as serious competition by various other groups and that an anti-Pharisee bias is a common motif in Second Temple Period writings (Josephus, Qumran, NT) and echoed in rabbinic texts. ${ }^{79} \mathrm{It}$ is unclear as to whether this bias was the popular view of Jewish society or only of certain segments therein but, at the very least, we can say that it did exist.

\footnotetext{
${ }^{75}$ Kalmin notes that "due to the New Testament's general hostility to Judaism, it is unlikely that the Bavli would have incorporated criticism of a Jewish group they tended to sympathize with ... from the New Testament," See Kalmin, Mitigating Tales, 167.

${ }^{76}$ See Mason, "Josephus's Pharisees," 4-10.

${ }^{77}$ Martin Pickup "Matthew's and Mark's Pharisees," in Neusner and Chilton, Historical Pharisees, 67.

${ }^{78}$ James VanderKam, "The Pharisees and the Dead Sea Scrolls," in Neusner and Chilton, Historical Pharisees, 236; VanderKam, "Pesher Nahum and Josephus."

${ }^{79}$ Another example of anti-Pharisee views reflected in rabbinic texts is the periscope in bKid 66a. Vered Noam points out that this text is a reaction to "the commonly held opinion that placed the blame for the breach with the Hasmonean dynasty at the Pharisees' door." See Noam, "The Story of King Jannaeus," 45.
} 


\section{BIBLIOGRAPHY}

Albeck, Hanoch. The Six Orders of the Mishna [Hebrew]. Jerusalem: Mosad Bialik/Tel Aviv: Dvir, 1988.

Baumgarten, Alfred. "The Name of the Pharisees. Journal of Biblical Literature 102 (1983).

Cohen, Shaye. "Josephus and His Sources." In Josephus in Galilee and Rome: His Vita and Development as a Historian. Leiden: Brill, 1979.

—. "Parallel Traditions in Josephus and Rabbinic Literature." In Proceedings of the Ninth World Congress of Jewish Studies. Jerusalem: World Union of Jewish Studies, 1986.

Ephron, Joshua. Studies in the Hasmonean Period [Hebrew]. Tel Aviv: Kibbutz Meuchad, 1980.

Epstein, Isidore. The Talmud: Sotah. London: Soncino, 1978.

Eshel, Hanan. The Dead Sea Scrolls and the Hasmonean State [Hebrew]. Jerusalem: Yad Ben Zvi, 2004.

Flusser, David. Judaism of the Second Temple Period. Vol. 1, translated by Azzan Yadin. Jerusalem: Magnes, 2007.

Garland, David. The Intention of Matthew 23. Leiden: Brill, 1979.

Goldstein, Jonathan. "The Hasmonean Revolt and the Hasmonean Dynasty." In The Cambridge History of Judaism. Vol. 2, edited by W. Davies and L. Finkelstein. Cambridge: Cambridge University Press, 1989.

Goodblatt, David. The Monarchic Principle: Studies in Jewish Self-Government. Tubingen: Mohr, 1994.

—. "The Place of the Pharisees in First Century Judaism: The State of the Debate." Journal for the Study of Judaism, 20:1 (1989).

Goodman, Martin. “A Note on Josephus, the Pharisees and Ancestral Tradition.” Journal of Jewish Studies 50 (1999).

Hengel, Martin, and Roland Deines. "E.P. Sanders' 'Common Judaism,' Jesus, and the Pharisees." Journal of Theological Studies 46, no. 1 (April 1995).

Hölscher, Gustav. s.v. "Josephus." In Paulys Realencyclopädie der klassischen Alertumswissenschaft 9. Stuttgart: J. B. Metzler, 1916.

Die Quellen des Josephus. Leipzig: Teubner, 1904.

Ilan, Tal. Integrating Women into Second Temple History. Peabody, Mass: Hendrickson, 1999.

- "Josephus and Nicolaus on Women." In Geschichte-Tradition-Reflexion, edited by Hubert Cancik, Hermann Lichtenberger, Peter Schäfer. Tübingen: Mohr Siebeck, 1996.

- Silencing the Queen: The Literary Histories of Shelamzion and other Jewish Women. Leiden: Brill, 2006.

Jones, Christopher. "Towards a Chronology of Josephus." Scripta Classica Israelica 21 (2002).

Josephus, Flavius. The Life and Against Apion. Translated by H. St. J. Thackeray. Cambridge, MA: Harvard University Press, 1926, 1956.

Kalmin, Richard Lee. Jewish Babylonia between Persia and Roman Palestine. New York: Oxford University Press, 2006. 
- Mitigating Tales: The Talmud's Narratives and their Historical Context. Oakland, CA: University of California, 2014.

Lambers-Petry, Doris. "Shelomzion ha-malka: The Hasmonean Queen and her Enigmatic Portrayal by Josephus.” In Internationales Josephus-Kolloquium, Dortmund 2002; Arbeiten aus dem Institutum Judaicum, edited by Jürgen U. Kalms and Folker Siegert. Münster: LIT, 2003.

Laqueur, Richard. Der Jüdische Historiker Flavius Josephus: Ein Biographischer Versuch auf neuer quellenkritischer Grundlage. Giessen: Münchow'sche Verlagsbuchhandlung, 1920.

Levine, Lee. "The Political Struggle between Pharisees and Sadducees in the Hasmonean Period" [Hebrew]. In Jerusalem in the Second Temple Period: Abraham Schalit Memorial Volume [Hebrew], edited by A. Oppenheimer, U. Rappaport and M. Stern. Jerusalem, Zalman Shazar, 1971.

Liddell, Henry George. An Intermediate Greek-English Lexicon: Founded upon the Seventh Edition of Liddell and Scott's Greek-English Lexicon. Oxford: Clarendon Press, 1945.

Mason, Steve. Flavius Josephus on the Pharisees: A Composition-Critical Study. Leiden: Brill, 1991, 2001.

—. "Josephus's Pharisees." In Neusner and Chilton, Historical Pharisees.

"Pharisaic Dominance before $70 \mathrm{CE}$ and the Gospels' Hypocrisy Charge (Matt 23:2-3)." Harvard Theological Review 83 (1990).

"War 1:107-114: The Pharisees and Alexandra Salome, I." In Flavius Josephus on the Pharisees: A Composition-Critical Study. Leiden: Brill, 1991, 2001.

"Was Josephus a Pharisee? A Re-Examination of Life 10-12." Journal of Jewish Studies 40, no. 1 (1989).

Neusner, Jacob. "Josephus' Pharisees." In Ex Orbe Religionum: Studia Geo Widengren Oblata. Vol. 1. Leiden: Brill, 1972.

- From Politics to Piety. Providence: Prentice Hall, 1973.

Neusner, Jacob, and Bruce Chilton, eds. In Quest of the Historical Pharisees. Waco, Texas: Baylor U. Press, 2007.

Noam, Vered. "The Story of King Jannaeus (b. Qiddušin 66a): A Pharisaic Reply to Sectarian Polemic." Harvard Theological Review 107:1 (January 2014).

Rivkin, Ellis. "Defining the Pharisees: The Tannaitic Sources," HUCA 40-41 (1970).

. "Scribes, Pharisees, Lawyers, Hypocrites: A Study in Synonymity." HUCA 49 (1978).

Saldarini, Anthony. "Delegitimization of Leaders in Matthew 23." Catholic Bible Quarterly 54 (1992).

- Matthew's Christian-Jewish Community. Chicago and London: University of Chicago Press, 1994.

—. "Pharisees," Anchor Bible Dictionary. Vol. 3. New York: Doubleday, 1992.
. Pharisees, Scribes and Sadducees in Palestinian Society. Wilmington, Delaware: Michael Glazier Inc., 1988.

Schalit, Avraham. "Internal Policy and Political Institutions" [Hebrew]. In The Hellenistic Age [Hebrew], edited by Avraham Schalit. Jerusalem, 1983.

Schiffman, Lawrence. "Pharisees and Sadducees in Pesher Nahum." In Minha Le-Nahum: Biblical and Other Studies Presented to Nahum M. Sarna in Honor of His 70th Birthday, edited by Marc Brettler and Michael Fishbane. Sheffield: JSOT, 1993. 
Schröder, Bernd. Die 'Väterlichen Gesetze': Flavius Josephus als Vermittler von Halachah an Griechen und Römer. Tübingen: Mohr Siebeck, 1996.

Schwartz, Daniel, trans. Flavius Josephus, Vita: Introduction, Hebrew Translation, and Commentary [Hebrew]. Jerusalem: Yad Ben Zvi, 2007.

—. "Josephus and Nicolaus on the Pharisees." Journal for the Study of Judaism 14 (1983).

—. "On Pharisaic Opposition to the Hasmonean Monarchy," In Studies in the Jewish Background of Christianity. Tübingen: J.C.B. Mohr, 1992.

Shatzman, Israel. "Success Followed by Envy: The Greek Tradition and Josephus" [Hebrew]. In Essays in Memory of Menachem Stern and Studies Following his Works [Hebrew]. Jerusalem: The Israel Academy of Sciences, 2002.

Smith, Morton. "Palestinian Judaism in the First Century." In Israel, Its Role in Civilization, edited by Davis, Moshe. New York: Israel Institute of the Jewish Theological Seminary of America, 1956.

Stern, Menahem. Greek and Latin Authors on Jews and Judaism. Vol. 1. Jerusalem: Israel Academy of Sciences and Humanities, 1976.

Thackeray, H. St. J. Josephus, The Jewish War. Cambridge, MA: Harvard University Press, 1927.

Ullmann, Lisa. Yosef Ben Matityahu [Titus] Flavius Josephus, History of the Jewish War Against the Romans [Hebrew]. Jerusalem: Carmel, 2009.

VanderKam, James. "Pesher Nahum and Josephus." In When Judaism and Christianity Began: Essays in Memory of Anthony J. Saldarini, edited by Alan J. Avery-Peck, Daniel Harrington and Jacob Neusner. Leiden: Brill, 2004.

—. "The Pharisees and the Dead Sea Scrolls." In In Quest of the Historical Pharisees, edited by Jacob Neusner and Bruce Chilton. Waco, Texas: Baylor U. Press, 2007.

Zeitlin, Solomon. Studies in the Early History of Judaism. Vol. 2. New York: Ktav, 1974. 